\title{
The Prospects of Irrigation Technology in the Tribal Districts of Odisha
}

\author{
Subhra Parida
}

\begin{abstract}
Odisha has always been competitive when it comes to mining and industrial activities, thanks to its abundant mineral content. Little does anyone know that agriculture is also an equally important sector which contributes around $19 \%$ to the Gross State Domestic product (GSDP). According to the Odisha Economic Survey 2018-19[1]GSDP grew at a rate of $8.4 \%$ as compared to $7.4 \%$ in the previous year. The mining, manufacturing and services sector have contributed significantly to the GSDP by about $10.8 \%, 18.5 \%$ and $41.6 \%$ respectively.Staterose up from $26^{\text {th }}$ rank in $1996-97$ to $16^{\text {th }}$ in 2016-17. This also tells us about the growing development process in the State which is occurring along the lines of Prof. Boeke's Dual economy model where the agriculture as well the manufacturing sector co-exist in an economy.But disappointinglythe pace of agricultural growthis gradually declining as compared to the other sectors. The major fallacies in the growth of the primary sector in the last few years are deficit rainfall, lack of proper infrastructure, low financial inclusion and low literacy level of farmers, sharecroppers and labourers.Undoubtedly theseaberrations can adversely impact farmer's economic and social wellbeing. According to the Odisha Economic Survey 2018-19 the monthly farm household income in 2012-13 was INR 4976 but when compared to India's average monthly farm household income of INR 6426, it seems inadequate. About 10.8 million people which is approximately $61.8 \%$ of the total workforce are involved in agricultural activities. The entirety of this agricultural workforce is responsible in contributing about $18-19 \%$ to the GSDP which seems a little disproportionate. In this process of developmentthe most affected communities are the backward tribes who do not have much of a say in the economy. This paper aims to find out the dependence between the productivity of crops on rainfall and how technology such as drip and sprinkler irrigation system can further help in alleviating this inconsistency in the tribal districts of Odisha.
\end{abstract}

Keywords: backward tribes, deficit rainfall, drip irrigation,dual economy.

\section{INTRODUCTION}

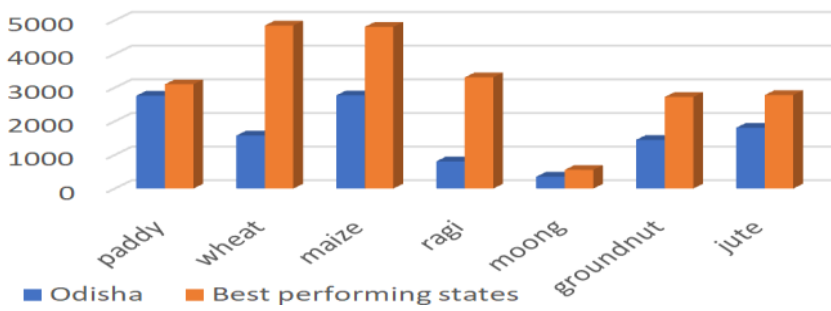

Fig.1 Yield per Hectare (Kg/Ha) of Different Crops

(Source: Agricultural statistics report 2016-17[2]; technical report on

EARAS (Agricultural statistics division - Directorate of Economics and Statistics, Odisha[3].)

Revised Manuscript Received on February 05, 2020.

* Correspondence Author

Ms. Subhra Parida*, Research Scholar, School of Humanities, Kalinga Odisha, India.

(c) The Authors. Published by Blue Eyes Intelligence Engineering and Sciences Publication (BEIESP). This is an open access article under the CC BY-NC-ND license (http://creativecommons.org/licenses/by-nc-nd/4.0/) Institute of Industrial Technology, Deemed to be University, Bhubaneswar,

Odisha is considered one of the poorest States of the country despite the ample mineral content and variable agroclimatic zones prevalent here. According to the Tendulkar Committee India's poverty rate reduced from $37.2 \%$ in 2004-05 to $21.9 \%$ in $2011-12$ whereas Odisha's poverty rate reduced from $57.2 \%$ in $2004-05$ to $32.6 \%$ in $2011-12$. Though it has shown improvements in its poverty reduction it doesn't seem sufficient enough when compared to neighbouring States such as Chhattisgarh, Jharkhand and Andhra Pradesh. With about $60 \%$ of the total workforce of the State involved in agriculture and allied activities, the State can depend on tapping the potential of the areas in agriculture which have remained latent or indigenous for a while now. Out of the 30 districts nine are tribal dominated. Mayurbhanj, Kedunjhar, Sundergarh, Kandhamal, Gajapati, Koraput, Rayagada, Malkangiri and Nabarangpur are the respective tribal districts. Leaving Malkangiri behind, the rest come under agro-climatic zone of the State and are known to be highly potential regions for MNREGA labourers. Being rich in natural resources but separated from the jostle of urbanisation, the agricultural practicesremain unexplored and traditional. Turmeric from Kandhamal district has been awarded a Geographical Indication tag from the Union Ministry of Commerce and Industry because of its oleo resin and natural oil content which imparts rich aromatic value and has remarkable healing properties. Unfortunately such crops are grown under the traditionalknowledge of tribal farmers inherited from their ancestors generating moderate amount of yield which leaves them withhardly any revenue surplus.

The Odisha State government has taken numerous steps in the past ten years to limit the constraints involved in the supply chain process such as protection from pests, harvesting, marketing, re-evaluating the Minimum Support Price time and again, introducing modern technology like HYV seeds, tools and equipmentetc. which have led to value addition of their products. The State Government has also put in a lot of effort to improve the management and technical skills of the farmers with the execution of varied schemes such as mapping of skills at district level by Orissa University of Agriculture and Technology, peer learning mechanism mobile based advisory etc. [4]. The question here lies in the fact that if there is a constant effort in utilising the knowledge and skills of farmers in the State then why have the yields not improved as compared to that of the other States such as Punjab, Gujarat or Tamil Nadu. As stated by eminent economists C. Rangarajan and S. Mahendra Dev agriculture in India can be revamped by limiting procurement, boosting productivity and consolidating land holdings.

Published By:

Blue Eyes Intelligence Engineering

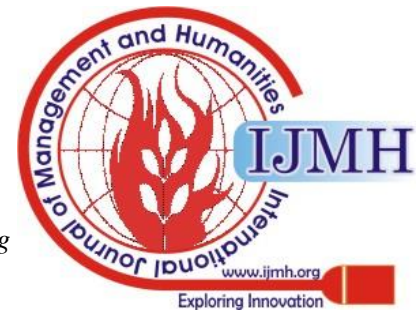




\section{The Prospects Ofirrigation Technology in the Tribal Districts of Odisha}

Given the short supply of land as an asset, productivity can only be increased by optimizing theinputs, one of them being irrigation. Out of all the inputs applied on the field, irrigation is the component which is indisposable in nature as compared to fertilisers and insecticides. Infrastructure, electricity and maintenance all add up to the costs of a farmer which naturally obligates a farmer to depend on Quiqiong Huang, Scott Rozelleet.al[5]irrigation contributed to increase in yield and farm income in China. If utility of irrigation can be maximised by minimising the costs, it can be treated as a panacea for any farm in any country. As perKinyeAsayehegn, ChilotYirgaet.al.[6]irrigation enables small land holders to adopt more diversified cropping patterns and to switch from low value staple production to high value market oriented production.The State government hopes to achieve the target of obtaining high quality yield by providing micro irrigation services to every farm under the 'Per Drop More Crop' scheme (Draft Agricultural Policy 2019)[4].

The tribal population in high lands of Odisha produce crops like rice (paddy), turmeric etc. without any modern technology which is also the reason why the yield is not much as compared to the non-tribal agricultural regions. The government plans to utilise their skills to encourage crop diversification with user -friendly technology to grow crops variety of fruits and vegetables (Agriculture Statistics,Odisha)[7].Tribal people prefer traditional techniques to increase the productivity. Traditional techniques can help in augmenting the fertility of the soil but if we have todeal with large scale production to feed an enormous population like that of India it is important to work on the efficiency parameters to obtain large scale production intact with high quality as well. It has been observed the lack of education is one of the reasons behind dearth of technology usage in this region. With proper amount of education farmers will be able to adapt to new variations of inputs which are climate resistant and nutritional as well. For example in Israel, various kinds of tangerines were grown which are heat resistant and include the same amount of nutritional values as those from China. P.S. Ward and SimrinMakhija (IFPRI) [8]state that crops such as DT rice and WII product of rice variety are drought resistant and can be grown in arid and semi-arid regions of the State.To enhance the productivity popularization of costeffective, eco-friendly production technologies should be encouraged (NareshBabu, A.K. Shukla et. al.)[9]. Butit has been reported that the Northern peninsula is experiencing groundwater depletion at a rapid rate due to excessive and uncalculated use of irrigation facilities. This makes efficiency and proper infrastructure more important in order to cut down wastage of water.

\section{ODISHA AND ITS TRIBAL POPULATION}

Article 366 (25) of the constitution of India refers to STs as those communities who are scheduled in accordance with Article 342 of the constitution. The central features of the Scheduled Tribes community were first established by the Lokur community[10]. The following are the features: primary sources of water such as rainfall. But according to like coffee, millets, turmeric, pulses, oilseeds, different

\section{Indications of primitive traits}

2. Distinctive culture

3. Shyness of contact with the community at large

4. Geographical isolation

5. Backwardness

As per the 2011 Census, $22.85 \%$ of the State's population comprises of tribal people. There are 62 different tribes including 13 Particularly Vulnerable Tribal Groups.About $44.7 \%$ of the State's total area is known as the Scheduled area in accordance with the orders the President of India issued under the 5th Schedule of the Government. The Scheduled area consists of Mayurbhanj, Koraput, Malkangiri, Rayagada, Nabarangpur, Sundergarh, Kandhamal, R.Udayagiri tehsil, Gumma and Rayagada blocks ofGajapati, Soroda tehsil excludingGazalbadi and Gocchapanchayats of Ganjam district, Kuchinda tehsil of Sambalpur district, Telkoi,Keonjhar - keonjhar, Champua and Barbil tehsils, Th. Rampur and Lanjhigarh blocks of Kalahandi district and Nilagiri block of Balasore district. This entire region is inhabited by $68.09 \%$ of the entire tribal population of the State which makes Odisha the third largest State after Madhya Pradesh and Maharashtra in terms of Tribal population. Out of all the districts and tehsils mentioned here this paper will focus on the nine districts as stated previously due to the skewness of tribal population. The rate of literacy among the Scheduled Tribes (ST) is $52 \%$ against that of $59 \%$ of the entire nation. The literacy rates among ST males and females are 64\% and $41 \%$ respectively. The major agricultural produce are rice, pulses (red gram and black gram), ragi, oilseeds (mustard, castor etc.) and vegetables. Certain districts are well known for their horticultural and floricultural produce. Many of the tribes depend on slash and burn kind of technique for sustenance making them shift from one cultivable area to another with no permanent source of residence.The land tenure system is also a big problem for the tribal farmers especially the women as they are not aware of the legalities involved (GadadharMohapatra)[11]. Landless, small and marginal farmers have to deal with food insecurity because ofirregularities involved in Public distribution system which leads them to into the problem of indebtedness. This is how a poverty stricken farmer gets stranded in the circle of poverty.

\section{Demography of Tribal Districts}

Out of the nine districts of Odisha Mayurbhanjis the most populated by Scheduled Tribe with respect to the total population of the district and also in the State. And the least populated among them is Gajapati. The literacy rate is also highest in Mayurbhanj district while it is the least in Nabarangpur district. Ironically the sex ratio is high among most of the tribal districts apart from Keonjhar and Koraput. For all the districts about $85-90 \%$ of the residents belong to rural area. While Rayagada is the most urbanized district among them, Malkangiri is the most backward district, Nabarangpur, Mayurbhanj, Gajapati, Kandhamal and Kalahandi follow. These six districts are also among the fifty most backward districts of the country according to Human Development Index rankings.

Published By:

Blue Eyes Intelligence Engineering

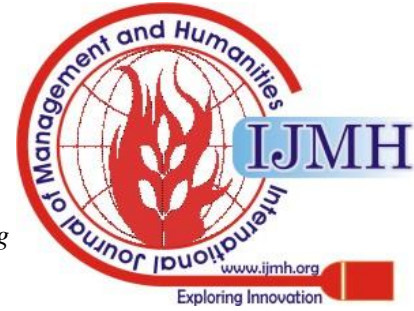




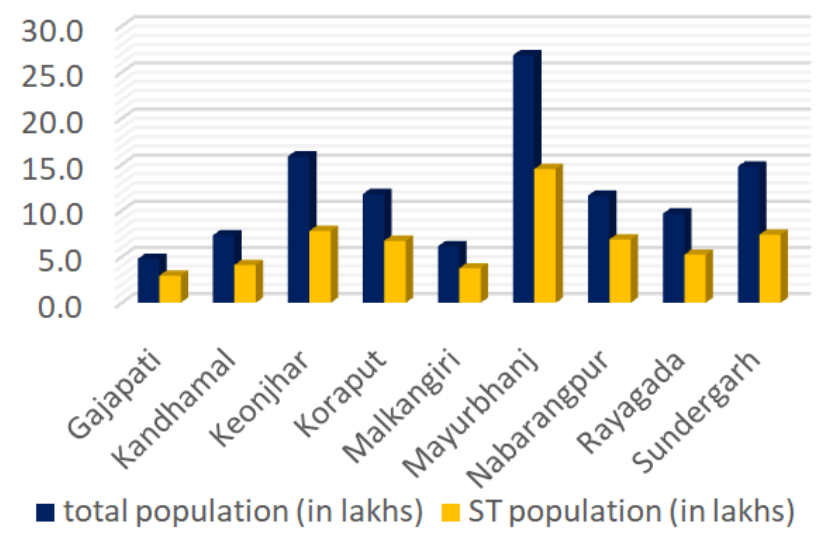

Fig.2. ST population with respect to the total population of the District (Source: Census 2011)

Table 1. Demography of tribal dominated districts

\begin{tabular}{|l|r|r|l|}
\hline \multicolumn{1}{|c|}{ District } & $\begin{array}{r}\text { literacy } \\
\text { rate (\%) }\end{array}$ & sex ratio & major occupancy \\
\hline Gajapati & 53 & 1043 & Agriculture (>90\%) \\
\hline Kandhamal & 65 & 1037 & varied \\
\hline Keonjhar & 68 & 988 & Agriculture (>80\%) \\
\hline Koraput & 49 & 1032 & Agriculture (>90\%) \\
\hline Malkangiri & 49 & 1004 & Agriculture (>90\%) \\
\hline Mayurbhanj & 84 & 1005 & varied \\
\hline Nabarangpur & 48 & 1007 & Agriculture (>90\%) \\
\hline Rayagada & 50 & 1048 & Agriculture $(>94 \%)$ \\
\hline Sundergarh & 65 & 957 & varied \\
\hline
\end{tabular}

Source: Census 2011

The major occupation of Gajapati, Malkangiri, Koraput, Nabarangpur and Rayagadais agriculture with about $90 \%$ or more of the inhabitants involved in agriculture or allied activities. Interestingly Kandhamal is famous for its production of turmeric and wild herbs on the contrary it suffers scarcity of water. While most of the economy of Mayurbhanj district is dependent on agriculture, the district also relies on various small scale industries for its survival. Major portion of Sundergarh's economy is dependent on mining activities because of its rich mineral content such as that of iron ore, manganese ore, limestone and dolomite. According to the Census 2011, women workers in agricultural comprised of about $65 \%$ of the total women workers in the State. Given the fact that around $70-80 \%$ of the total workforce in the nine districts are agriculture workers, it can be deciphered that the tribal population is dependent on agriculture for their economic, social and psychological wellbeing. In order tounderstand their household economy the paper will further analyse the crop production and productivity with regard to their dependence on rainfall.

\section{AGRICULTURE IN THE TRIBAL DISTRICTS}

Table 2. Agriculture Statistics

\begin{tabular}{|r|l|r|r|}
\hline No. & \multicolumn{1}{|c|}{ District } & $\begin{array}{r}\text { Gross cropped } \\
\text { area (lakh Ha) }\end{array}$ & $\begin{array}{c}\text { average } \\
\text { rainfall (mm) }\end{array}$ \\
\hline 1 & Gajapati & 1.3 & 1926 \\
\hline 2 & Kandhamal & 1.3 & 1523 \\
\hline 3 & Keonjhar & 3.7 & 1488 \\
\hline
\end{tabular}

\begin{tabular}{|r|l|r|r|}
\hline 4 & Koraput & 3.6 & 1567 \\
\hline 5 & Malkangiri & 2.0 & 1668 \\
\hline 6 & Mayurbhanj & 5.6 & 1600 \\
\hline 7 & Nabarangpur & 2.7 & 1300 \\
\hline 8 & Rayagada & 2.5 & 1350 \\
\hline 9 & Sundergarh & 3.9 & 1387 \\
\hline
\end{tabular}

Source: District Irrigation Plan 2015,Dept. of water resources, Odisha[12]

Among all the districts, Mayurbhanj is the district with the maximum amount of cropped area and Gajapati and Keonjhar being the least. While rainfall is highest in Gajapati, the district whose dependence on rainfall to suffice its agricultural purposes is Kandhamal. The reliance on rainwater is more in Kandhamal is because of lack of natural water reserves. So is the condition of Nabarangpur and Rayagada. In 2015-16 Odisha suffered a huge setback because of drought which struck 27 different districts out of 30. Since then the State has been suffering from regular episodes of drought. In 2018 Odisha declared nine districts as drought prone areas. Out of those nine districts, Nabarangpur and Sundergarh were also among the drought hit districts. In the year 2019 also State had to face drought like conditions. These regular occurrences of drought are mainly due to severe mining and extraction activities which are adversely affecting the environment leading to lowering of water table and disrupting the hydrological cycle among the numerous environmental degradations. Given the huge reliance on rainfall, if the water table reduces with the decrease in rainfall many of these districts will be severely affected.

Production will decrease which will decrease productivity because of which sale of products will decline and ultimately farmer's income will drop. Interestingly there are certain regions which receive excessive rainfall (more than annual average rainfall). If this surplus reserve can be channelled to the arid regions of the tribal districts, it can help them cope with deficit rainfall.

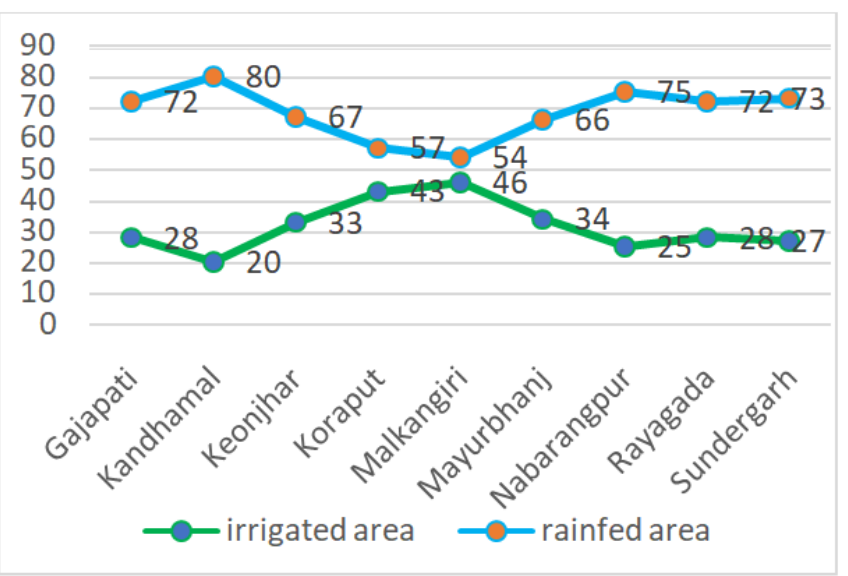

Fig.3 Percentage of irrigated area out of the total gross cropped area (Source: District Irrigation Plan 2015, Dept. of water resources, Odisha)

Published By:

Blue Eyes Intelligence Engineering

\& Sciences Publication

(C) Copyright: All rights reserved.

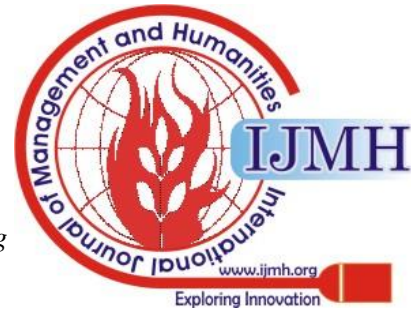




\section{The Prospects Ofirrigation Technology in the Tribal Districts of Odisha}

Table 3. Productivity of crops $(\mathrm{Kg} / \mathrm{Ha})$ in each District:

\begin{tabular}{|l|r|r|r|r|r|r|r|r|r|}
\hline Crops & Gajapati & Kandhamal & Keonjhar & Koraput & Malkangiri & Mayurhanj & Nabarangpur & Rayagada & Sundergarh \\
\hline Cereals & 1519.5 & 1824 & 2041.5 & 2921 & 2043 & 1979 & 3040 & 2541 & 2367.5 \\
\hline Coarse cereals & 1142 & 1661 & 1660 & 2107 & 1753 & 1414 & 2994 & 2278 & 1938 \\
\hline pulses & 546 & 477 & 556 & 497 & 494 & 566 & 487 & 698 & 525 \\
\hline oilseeds & 854 & 381 & 483 & 431 & 1045 & 796 & 669 & 490 & 569 \\
\hline Fibre & 505 & 471 & 1331 & 753 & 610 & 836 & 849 & 569 & 1018 \\
\hline sugarcane & 70833 & 52000 & 68000 & 78978 & 50000 & & 63060 & 64583 & 70444 \\
\hline vegetables & 13477 & 15667 & 14616 & 13735 & 13072 & 14079 & 13280 & 13644 & 13549 \\
\hline spices & 2696 & 8538 & 2463 & 5880 & 2033 & 3267 & 1453 & 3377 & 1944 \\
\hline
\end{tabular}

Source: Odisha Agriculture Statistics 2013-14.

From table (3) productivity of distinct crops in each district can be inferred. Cereals include paddy and wheat. Coarse cereals comprise of maize, pearl millets, ragi, jowar and bajra. Pulses include arhar, mung, urad, cowpea, lentil etc. Oilseeds include groundnut, sesamum, castor, niger, sunflower, safflower, soyabean etc. Fibre crops include Jute, mesta, sunhemp and cotton. Spices include chilli, coriander, Garlic, turmeric, and Ginger.WhileNabarangpur yields the maximum amount of cereals, Gajapati yields the lowest. Interestingly cereal production in Gajapati utilises around $80 \%$ of the irrigated area out of the total cropped area for cereals in the district. Rayagada is doing well when it comes to pulses but most of it israinfed. For oilseeds Malkangiri ranks at the top though producing most of it on the irrigated area. Keonjhar is the district which is doing well when it comes to Fibre production again most of it is rainfed. The same goes for other crops as well. In all the cases there seems to be a paradox between the yield and the amount of irrigation potential created. In few of the districts the potential utilised is insignificant as the entire production is rainfed. The irrigation potential that has been created demands a huge share in budget expenditure. If the utilization is below optimum level then the faults in service delivery should be immediately recognized and an Ad Hoc committee should be set up. This will impart regulatory governance to tackle the issues at the earliest. Huge grants received from International agencies specifically the World Bank, Japan International Co-operation Agency and Asian Development Bank have been put to use but the results are yet to be known.

Percentage of irrigated area out of the total cropped area for each crop:

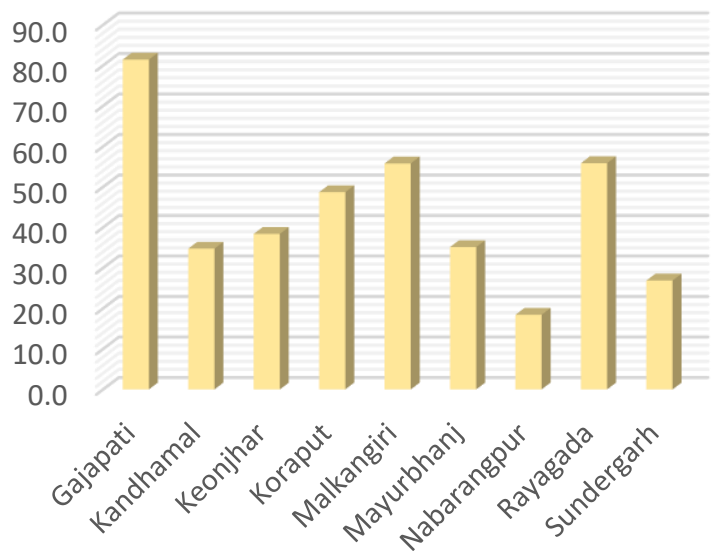

Fig.4. Cereals

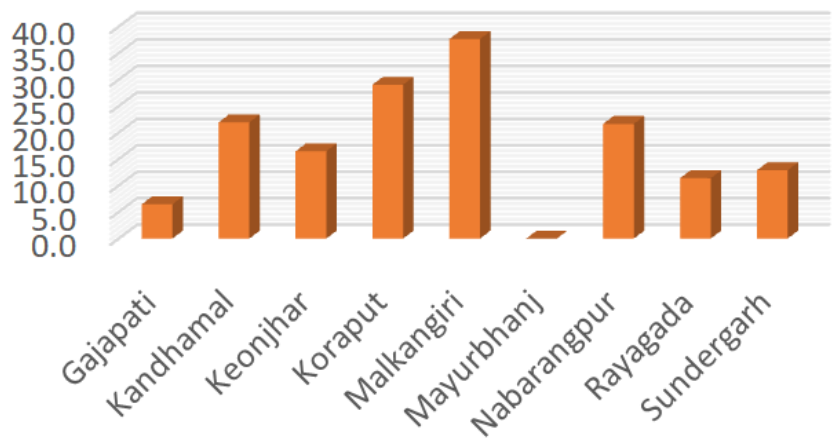

Fig.5. Coarse cereals

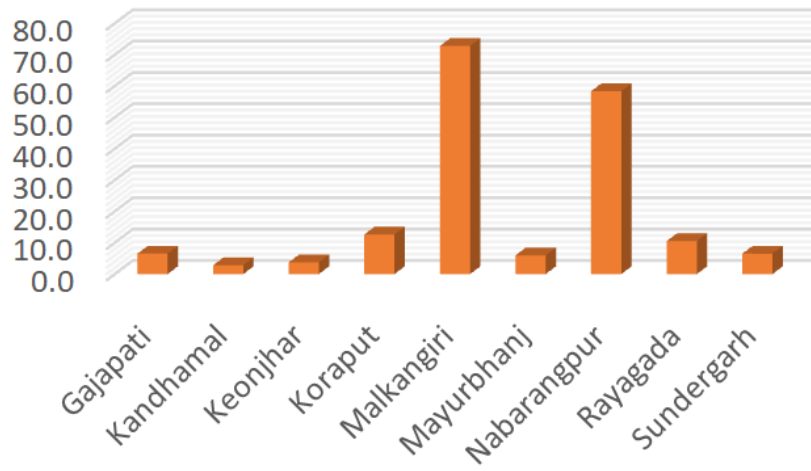

Fig.6. Pulses

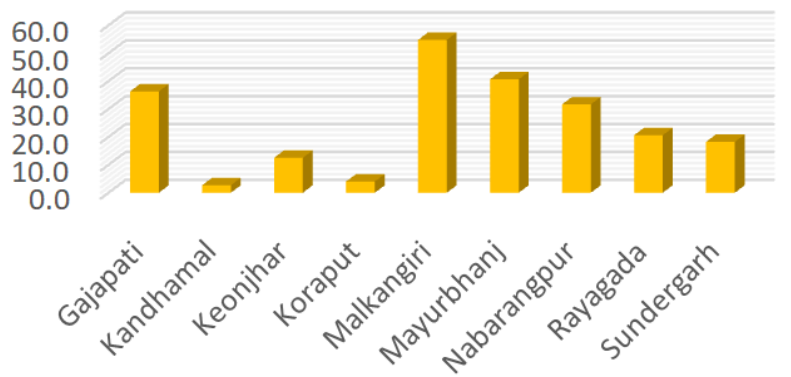

Fig.7. Oilseeds

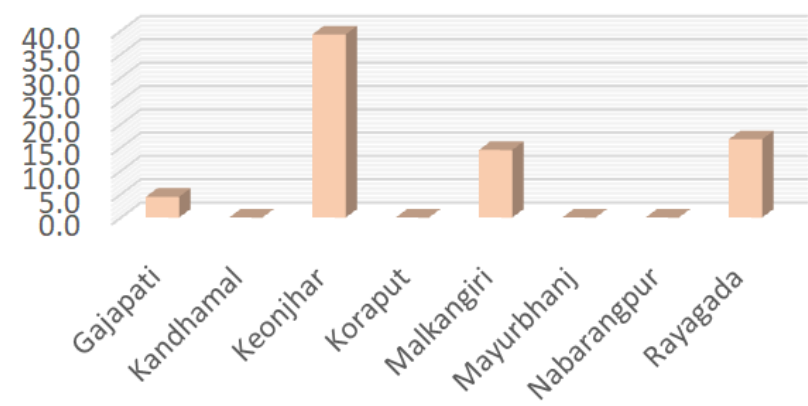

Fig.8. Fibre

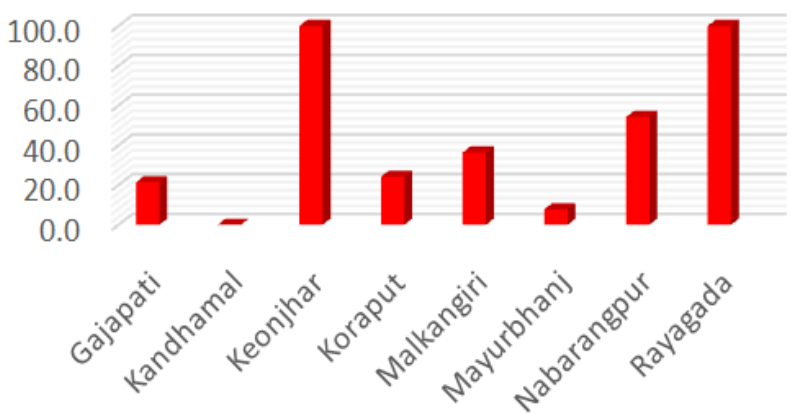

Fig.9. Horticulture and Plantation

Published By:

Blue Eyes Intelligence Engineering

\& Sciences Publication

(C) Copyright: All rights reserved.

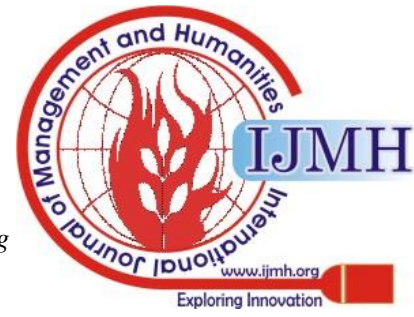




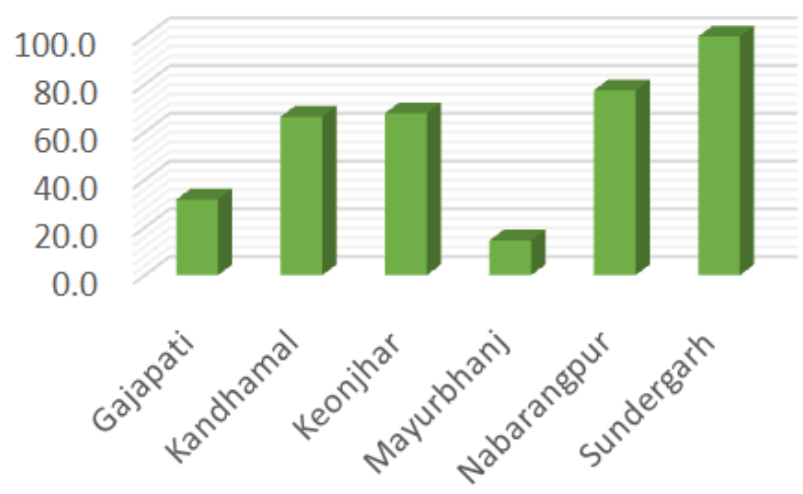

Fig.10. Vegetables

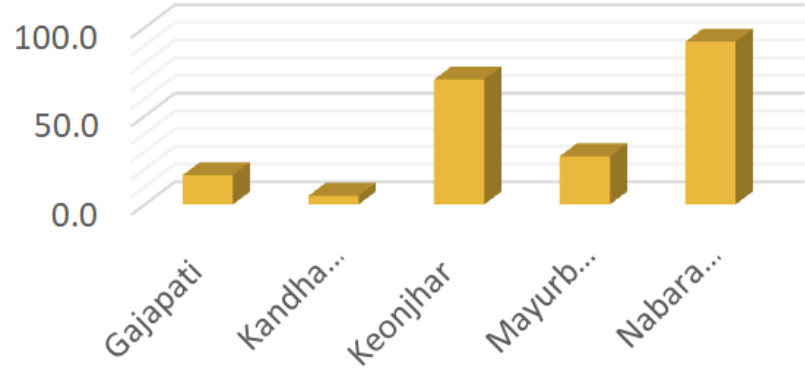

Fig.11. Spices (Source: District Irrigation Plan 2015; Odisha Agriculture Contingency Plan 2011.)

Table 4: Irrigation potential created (Ha)

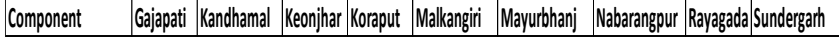

\begin{tabular}{|l|r|r|r|r|r|r|r|r|r|}
\hline AlBP & 3629 & 0 & 73478 & 13088 & 5169 & 48415 & 12368 & 7549 & 8544 \\
\hline Har Khet Ko Pani & 1906 & 1675 & 49624 & 34102 & 7432 & 36597 & 17680 & 82726 & 78556 \\
\hline Per drop more crop & 530 & 5066 & 6340 & 16692 & 3967 & 6488 & 4098 & 11740 & 0 \\
\hline PMKSYWatersheds & 1235 & 353 & 14797 & 15121 & 2948 & 82093 & 47554 & 32228 & 11500 \\
\hline $\begin{array}{l}\text { Convergence with } \\
\text { MGNREGA }\end{array}$ & 0 & 2898 & 10504 & 5428 & 6001 & 20829 & 0 & 10530 & 0 \\
\hline State Plan Scheme & 50700 & 1512 & 27158 & 10700 & 6395 & 39107 & 4673 & 3092 & 39500 \\
\hline Grand Total & 58000 & 12586 & 181901 & 95131 & 31912 & 233529 & 86373 & 147865 & 138100 \\
\hline
\end{tabular}

Source: Department of water resources, Odisha

The table 4 displays the Short Term strategic action plan under a five year period from 2016-17 to 2020-21. In order to bring the remaining rainfed area under the purview of irrigation schemes, this plan has been adopted. Five major schemes for irrigation development have been chalked out under which the command area or irrigation potential will be built. Command area isthe area around dam or a river valley project that can derive the benefits out of the facilities provided by the infrastructure built. Accelerated Irrigation Benefit Programme initiated in 1996-97 has undertaken several major, mediumand minor projects under its purview especially in tribal and drought prone areas. Recently it has been merged with Pradhan Mantri Krishi Sinchai Yojana (PMKSY) to fast-track irrigation projects. While 'HarKhetkoPani' aims to provide irrigation facilities to every farm, 'per drop more crop' aims to increase water use efficiency on every farm in order to minimise wastage of resources. It aims to adopt micro irrigation strategies to benefit crops by application of water to the roots and decrease water logging. It also enhances the nutrients of the soil maintaining its fertility and supports proper growth of the plants. PMKSY watershed programme was developed in 2017 under the purview of Ministry of rural development in order to conserve natural resource such as ground water table which is rapidly depleting and harvest rainwater in order to recharge ground water. With that it also plans to harness farmer welfare projects for value addition of their products which will further raise farm household income. Convergence with MGNREGA is another brainchild of Ministry of rural development in orderto benefit rural household especially Self-Help Groups and Vulnerable households with job opportunities in creating catchment area, orchards, nurseries, encouraging tourism etc.

\section{FARM INCOME AND TRIBAL POPULATION}

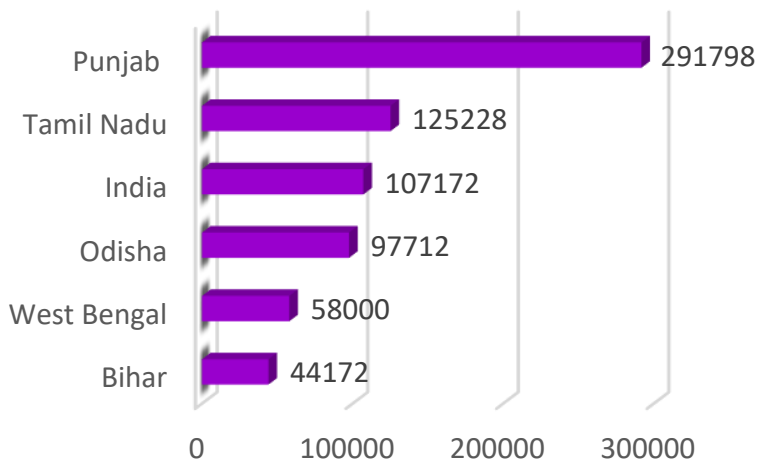

Fig.12. Annual Farm Household Income (INR) (Source: NABARD Survey Report.[13])

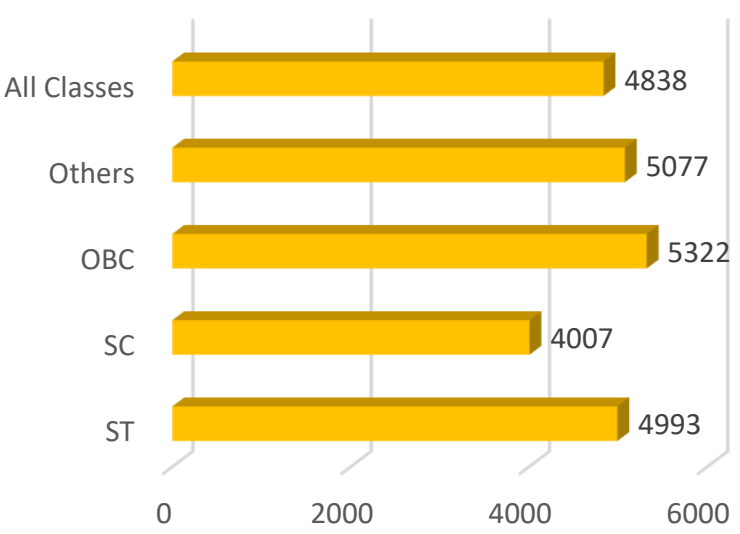

Fig.13. Social group wise annual monthly income (INR) of agriculture households in Odisha (Source: Doubling of Farmer's Income by 2022, ICAR report.[14])

Odisha's average annual farm household income has definitely seen a revolutionary change from INR 47000 in 2015-16 to INR 97712. Government has taken up several measures in order to encourage modern technology, crop diversification, financial inclusion, fisheries, poultry, dairy, honey farming, sericulture, horticulture etc. to increase farmer's income. This is one of the reasons why farm household income has increased 7 times from 2002 to 2016. Despite this sea change in income level it still hasn't been able to touch average farm household income of the country. The second figure States the average monthly farm household income of various social groups in Odisha. The annual income of STs is around INR 59916 which is 61\% of Odisha's average annual farm income.

Published By:

Blue Eyes Intelligence Engineering \& Sciences Publication

(C) Copyright: All rights reserved.

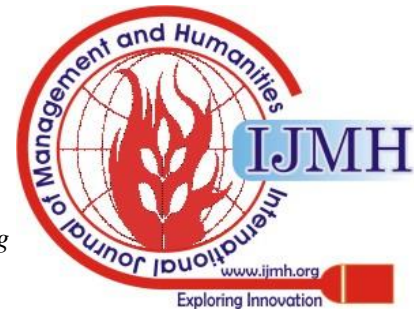




\section{The Prospects Ofirrigation Technology in the Tribal Districts of Odisha}

According to Depth and severity of poverty in rural Odisha report by Department of Economics and Statistics, government of Odisha [15], Khurda ranks the least among the districts in context of Poverty Head Count Ratio whileRayagada, Gajapati and Koraput are the severely affected districts. Poverty Head Count Ratio measures the proportion of population that exists below the poverty line. The six other districts are also struck by poverty and remain below the State average. This proves that the tribal districts do not have much of a contribution in increasing annual farm household income. The report was organized taking into consideration Census 2011. The India State Hunger Index 2009 [16]prepared by the International Food and Policy Research Institute in consultation with the Union and seventeen State Governments is given below.

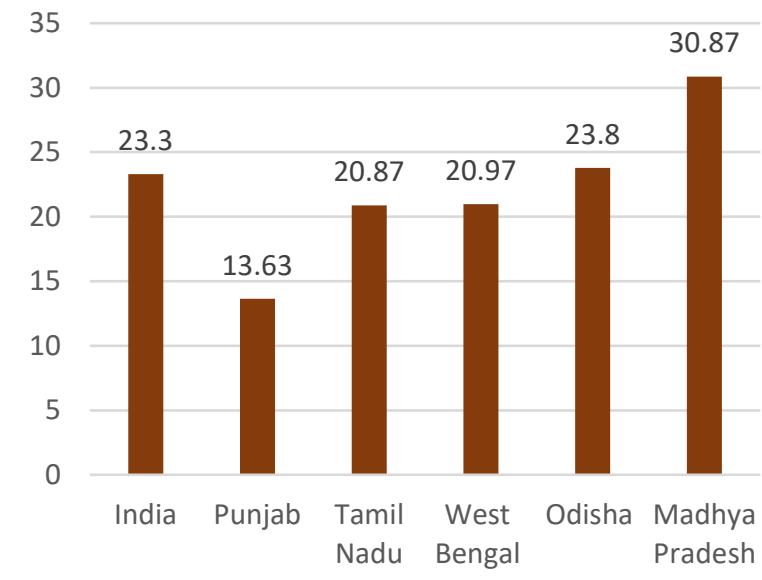

Fig.14. India State Hunger Index Score (Source: India State Hunger Index, IFPRI 2009)

Hunger Index is a tool that measures hunger globally using four indicators namely undernourishment, child stunting, child wasting and child mortality. India's rank in 2009 was 66while in 2019 it is 102 among 117 countries which proves India's dilapidated condition despite the Food Security Act and nutritional supplements made available. Child stunting due to malnutrition is one among the major anomalies visible in children in Odisha. Odisha'srural people predominantly dependon agriculture for their sustenance. Despite all the efforts to improve this sector if the State has to deal with poverty and hunger issues the Government undeniably needs to mend its waysin order to mitigate such discrepancies.

\section{MICRO IRRIGATION - THE NEED OF THE HOUR}

Drip irrigation can help induce modern agro-technology into this sector which is still a form of luxury for many farmers in Odisha. Drip irrigation can regulate the economies of scale with less use of electricity and less water consumption, thereby reducing the costs. With less cost a farmer can work on marketing his products and increase his revenue and optimize profits as well. According to World Bank report 2014, drip irrigation achieved large scale benefits for a small province like Balochistan, Pakistan [17]. The region completely arid dependent entirely on groundwater for its sustenance. When the Government of Balochistan and World Bank came together by initiating underground channels or karezes from nearby aquifers to the farms creating the perfect scenario for drip irrigation. India is also not far behind in executing drip irrigation. Karnataka will build Asia's biggest drip irrigation project in Bhagalkot district with the technical support of Israel. The project aims to utilise the backwaters of Almatti and channelize the water to the district. With the help of this project around 6000 farmers will be benefited. The advantage of drip irrigation lies in the fact that it can supply water to dry lands, reduce electricity charges, ensure the fertility of the soil, eradicate the involvement of subsidies that pile up and burden the exchequer, replace the schemes and programs which are credit disbursing in nature but not credit ensuring neither for the farmers or for the banks. It can also help in increasing farm household income instead of alluring them into windfall gains.

Table 5. Irrigation Potential (Ha) to be created under PDMC during 2016-21

\begin{tabular}{|c|c|c|c|c|}
\hline \multirow[t]{2}{*}{ District } & \multicolumn{2}{|c|}{ Drip Irrigation } & \multicolumn{2}{|c|}{ Sprinkler irrigation } \\
\hline & Non DPAP & DPAP & Non DPAP & DPAP \\
\hline Gajapati & 100 & & & \\
\hline Kandhamal & & 4474 & & 1831 \\
\hline Keonjhar & 240 & & 6100 & \\
\hline Koraput & 8346 & & 8346 & \\
\hline Malkangiri & \multicolumn{4}{|c|}{3967} \\
\hline Mayurbhanj & 1409 & & 3392 & \\
\hline Nabarangpur & 4098 & & 3350 & \\
\hline Rayagada & & 11740 & & \\
\hline Sundergarh & \multicolumn{2}{|c|}{14000} & \multicolumn{2}{|c|}{20000} \\
\hline
\end{tabular}

Source: Department of water resources, Odisha

*DPAP-drought Prone Area Programme

According to the 'Per drop moreCrop' [18] small, medium and large farmers will be benefitted with micro irrigation technology such as drip and sprinkler irrigation. The other reasons behind promoting this scheme is to improve fertigation and to provide employment opportunities to skilled and unskilledlabour. Fertigation [19] is the inclusion of fertilisers and water soluble nutrients in to the irrigation system for optimal and homogenous spread of essential elements in the field. The primal focus will be given to drought prone or arid regions. Assistance is limited to 5 Ha per beneficiary for irrigation of micro irrigation system. Farmers who have opted for organic farming or have taken land under lease are also eligible for a financial assistance. The beneficiaries are also eligible for subsidy.

\section{CONCLUSION}

Agriculture has always been the backbone of any nation. It not only acts as the building block for the economy but also is a panacea at the times of distress. Majority of the world economieshave developed along the lines of Rostow's Five stage economic growth model.

Published By:

Blue Eyes Intelligence Engineering

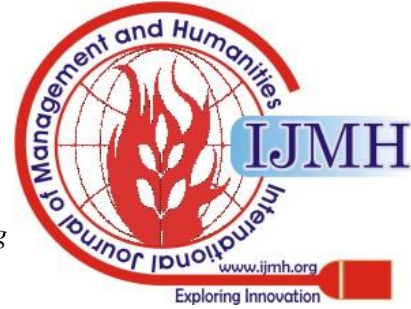


From being a traditional society to the age of high mass consumption, from being an agrarian economy to evolving into an economic superpower, from being an autarky to developing into an open economy every other nation has strived to become politically sound and competitive in every way possible. India claims to be in stage 3 of the growth model which is the 'Take- off' stage where all the industrialisation along with modernization of the society happens. Having said thatNobel LaureateDr. Joseph Stiglitz has a different point of view when it comes to India's development. He statesIndia is the country which will be most affected by climate change because of its unsustainable agricultural practices. This is a matter of serious concern given the fact that around $61.5 \%$ of the working population is engaged in agricultural activities. Even the environment is being largely affected by unskilled and obsoletefarming practices leading to wastage of resources, land degradation, soil erosion, irregular hydrological cycle, depleting ground water table. This can lead to dampening of the growth of the economy. Low yield of food-grainswould mean damaging the credit-worthiness of the farmers and labourers. For a state like Odisha it could mean a catastrophic loss. In order to take charge of the situation policy governance should be addressed in order to fast-track the implementation of schemes and curb the errors. Regular updates regarding the progress of a scheme should be made essential. Also the activities of the secondary sector should be delimited. Illegal Mining activities and disruptive industrialisation work prevalent in the tribal districts of Odisha need to be cut off.

China and Vietnam are perfect examples in front of India. The average land holding size for India is around 1.2 Ha, land holding size in China is around $0.6 \mathrm{Ha}$ and even less for Vietnam.That saidit is admirable to know China and Vietnam are better producers and exporters than India in case of rice, cereals, vegetables andsea-food. The reasons behind this achievement are quick and transparent land reform measures, shift from land intensive to high value labour intensive products, easy market access and sound macroeconomic policy conditions such as that of maintaining the inflation rate while the price of foodgrains rises. It is interesting to know how $56 \%$ of China's agriculture is technology driven [20]. India is also in the process of becoming a technological superpower.Andhra Pradesh, Karnataka, Gujarat, Maharashtra and Tamil Nadu are the major users of micro-irrigation technologies under Pradhan MantriKrishiSinchaiYojana. Using the Malmquist productivity Index we can measure the superiority of these States in agriculture over Odisha. But it is important to become science and technology driven while keeping in mind the fiscal deficit target as well. The State has declared to reduce KALIA (Krushak Assistance for Livelihood and Income Augmentation) assistance from INR 10,000 to INR 4,000. PM-KISAN is to replace this scheme to financially support the State's budget. While this can be relieving for the State's balance sheets but it might not be the same for the farmer. Income support schemes should not be politically driven as it would discourage rural workforce if such constant replacements get in the way of their payment. Paper work and delay in credit disbursal would diminish their confidence in the financial institutions. In order to spread the word State government should make them financially sufficient and introduce them to user friendly technology via correspondents.Underperforming and obsolete schemes should be removed and the funds should be diverted towards programmes which have an organized way of embarking. Delivery gaps should be removed. If farmers are provided proper incentives for their labour it will encourage them to adopt modern technology which will result in simultaneous employment generation in agriculture and agro based industries both. In one way or the other technology can help accelerate job opportunities, keep environment safe and empower the farmers.

\section{REFERENCES}

1. 1.Economic Survey 2018-19. Government of Odisha. Retrieved from https://pc.odisha.gov.in/Download/Economic_Survey_2018-19.pdf.

2. 2.Annual report on agriculture 2016-17. Retrieved from http://agricoop.nic.in/sites/default/files/Annual_rpt_201617_E.pdf.

3. 3.Report on EARAS, Department of Economics and Statistics, Government of Odisha. Retrieved From http://www.desorissa.nic.in/earas.html.

4. 4.Draft Agricultural Policy 2019. Government of Odisha. Retrieved from

http://agriodisha.nic.in/Content/pdf/DRAFT\%20AGRICULTURE\%2 0POLICY\%202019.pdf.

5. 5.Quiqiong Huang, Scott Rozelle, David Dawe, Jikun Huang and Jinxia Wang (2005). Irrigation, poverty and Inequality in rural China. The Australian Journal of Agricultural and Resource Economics.

6. 6.KinfeAsayehegn, ChilotYirga and SundaraRajan (2011). Effect of small-scale irrigation on the income of rural farm households: The case of LaelayMaichew District, Central Tigray, Ethiopia. Journal of Stored Products and Postharvest Research Vol. 2(10), pp. 208 - 215.

7. Odisha agriculture statistics 2013-14. Retrieved from http://agriodisha.nic.in/content/pdf/Agriculture\%20Statistics_201314.pdf.

8. $\quad$ 8.P.S. Ward and SimrinMakhija (2018). New modalities for managing drought risk in rainfed agriculture: Evidence from a discrete choice experiment in Odisha, India. World Development. Elsevier.

9. 9.NareshBabu, A.K. Shukla, P.C. Tripathi and ManoranjanPrusty (2015). Traditional Cultivation Practices of Turmeric in Tribal Belt of Odisha. Journal of Engineering Computers \& Applied Sciences (JECAS) Volume 4, No.2.

10. Lokur Committee report. Retrieved from https://tribal.nic.in/writereaddata/AnnualReport/LokurCommitteeRep ort.pdf

11. GadadharMohapatra (2012). Hunger and Coping Strategies among Kondh Tribe in Kalahandi District, Odisha (Eastern India). Transcience (2012) Vol. 3, Issue 2.

12. District Irrigation Plan, District Level Implementation Committee, Department of water resources, Odisha. Retrieved From http://www.dowrodisha.gov.in/

13. 13.NABARD All India Rural Financial Inclusion Survey 2016-17. Retrieved

From https://www.nabard.org/auth/writereaddata/tender/1608180417NABA RD-Repo-16_Web_P.pdf

14. Doubling of Farmer's Income by 2022, Strategy document for Odisha. $\quad$ Retrieved $\quad$ From http://icar-nrri.in/wpcontent/uploads/2019/02/2.-Odisha-Doubling-Farmers-Income-by2022.pdf

15. 15.Depth and severity of poverty in rural Odisha report by Department of Economics and Statistics, government of Odisha. Retrieved

http://www.desorissa.nic.in/pdf/Depth\%20and\%20severity\%20of\%20 poverty\%20in\%20Rural\%20Odisha.pdf

16. India State Hunger Index 2009. Retrieved From https://www.globalhungerindex.org/pdf/en/2009.pdf

17. World Bank feature story on drip irrigation at Balochistan (2014) Retrieved

Fromhttps://www.worldbank.org/en/news/feature/2014/06/16/pakista n-small-scale-irrigation-large-scale-benefits-for-balochistan

18. Per drop more crop, Pradhan MantriKrishiSinchaiYojana. Retrieved From

Published By:

Blue Eyes Intelligence Engineering 
The Prospects Ofirrigation Technology in the Tribal Districts of Odisha

https://pmksy.gov.in/microirrigation/index.aspx

19. 19.A. Raja Gopala Reddy, K. N. Tiwari and Santosh D.T. (2017). Yield Response of Turmeric (Curcuma longa L.)under Drip Fertigation and Plastic Mulch Conditions. International Journal of Pure and Applied Bioscience.

20. YunbiXu and Jiayang Li (2017). Agriculture and crop science in China: Innovation and Sustainability. The crop journal 5, Science Direct.

\section{AUTHOR'S PROFILE}

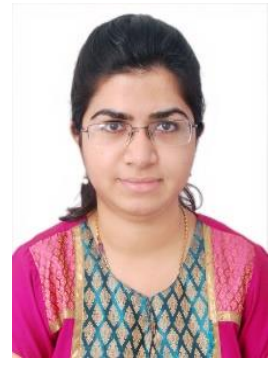

Ms. Subhra Parida has completed her postgraduation in Science from Gokhale Institute of Politics and Economics, specializing in the field of agribusiness economics. She is currently pursuing Ph.D. at KIIT School of Humanities. Her current area of research is 'Indian Agriculture'. She has qualified UGC NET and has also co-authored a research paper titled 'KALIA scheme: Contours, prospects and Challenges for Agricultural Productivity.' It was published in a Scopus-indexed Journal in the year 2019.

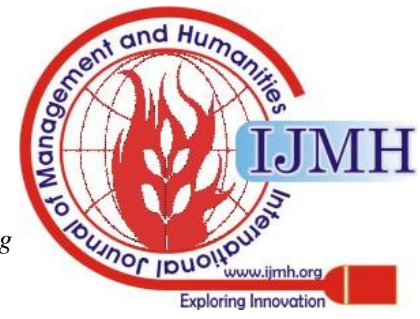

